\title{
Obituary: Remembering Lawrence M. Clopper
}

Larry Clopper, 1930-2014, was professor emeritus at Indiana State University, Bloomington, one of the Records of Early English Drama (REED) project's first editors, and one of Early Theatre's first board members. He died in Bloomington, Indiana this past spring, 7 June 2014.

I first met Larry at the Medieval Drama Seminar at the Modern Language Association in Chicago in 1973 when Margaret Dorrell Rogerson and myself, who were editing the York records, Larry, who was editing the Chester records, and David Galloway, who was editing the Norwich records, had been invited to give papers on our work. At that meeting the idea of REED was born and from the beginning Larry was an active partner. His edition of the Chester records was well advanced by the time REED was operational in 1976 and the fledgling editorial team in Toronto was able to form REED's editorial policies as two very different collections - Chester and York were being processed. Both collections were published in 1979. Larry was a longstanding member of the REED advisory board from the beginning of the project. Although his scholarly interests widened after the publication of the REED: Chester volume to include other areas of Middle English literature such as Piers Plowman, he responded gamely to the suggestion of a second edition of his Chester records in the context of the records of Cheshire edited by Elizabeth Baldwin and David Mills. This collection was published in 2007, almost thirty years after his original research. All three editors attended the launch in Chester where those present were treated to a spirited but amicable debate between Larry and David — standing on the streets of Chester in the pouring rain - about the pageant route. We note with sadness that Larry and David — two great REED men of Chester — have died within a year of each other.

Alexandra F. Johnston (ajohnsto@chass.utoronto.ca), professor emerita in the English department, University of Toronto, is also the founder of Records of Early English Drama. 
Larry's interests were varied: medieval literature, culture, and intellectual history; Middle English and early modern drama; Franciscans, Lollards, Langland, and the Gawain poet. His important contributions to the study of early theatre and its cultural context appeared particularly in his controversial book Drama, Play and Game: English Festive Culture in the Medieval and Early Modern Period (2001), for which he deservedly won the David Bevington Award. He liked and courted controversy, and that was part of his charm. And his impact on younger scholars was huge. He made people think hard and defend carefully what they thought — to him and to others - even while provoking further debate. He loved an argument and would defend his ideas with great vigour, but such debates were invariably followed by a glass of good wine or a great meal in a restaurant he had just discovered. He will be missed by all of us in the REED and Early Theatre community. 